\title{
Influence of an Intramammary Infusion at Drying-Off of Combined Penethamate Hydriodide, Benethamine Penicillin, and Framycetin Sulfate on Intramammary Infections and Somatic Cell Counts in Dairy Sheep
}

\author{
B. Linage and C. Gonzalo ${ }^{1}$ \\ Departamento de Producción Animal, Facultad de Veterinaria, Campus de Vegazana, Universidad de León, 24071-León, Spain
}

\begin{abstract}
The dynamics of intramammary infection (IMI) during the dry period were studied in 435 half-udders of 229 Assaf ewes, belonging to 2 flocks with high and medium IMI prevalences. Ewes were randomly assigned to 2 lots: 1) treated lot (TL) with 223 half-udders (118 ewes), which received complete dry therapy (1 syringe/ teat) of an antibiotic combination containing $100 \mathrm{mg}$ of penethamate hydriodide, $280 \mathrm{mg}$ of benethamine penicillin, and $100 \mathrm{mg}$ of framycetin sulfate, and 2) control lot (CL) with 212 nontreated half-udders (111 ewes). Two samplings per half-udder were carried out on 2 different days in the $5 \mathrm{~d}$ preceding drying-off, and 2 other samplings were again carried out in the 5 first $d$ of the postpartum period. The length of the dry period averaged $109.0 \mathrm{~d}$. Cure, persistent infections, reinfection, and new infection rates were 81.7, 12.8, 5.5 , and $7.9 \%$, respectively, for TL and $13.3,70.4,16.3$, and $22.8 \%$, respectively, for the CL. The prevalence of IMI decreased significantly from $48.9 \%$ at drying-off to $13.0 \%$ at lambing for the TL, but it did not vary for the CL (46.2 and 52.4\%, respectively). Within the TL, IMI prevalence significantly diminished for Staphylococcus (41.3 to $9.9 \%$ ) and Streptococcus (5.8 to $1.8 \%$ ) genera, and more specifically this decrease was most evident for Staphylococcus epidermidis and Streptococcus agalactiae species. Log somatic cell count (SCC) diminished significantly between drying-off (5.68) and lambing (5.33) in the TL, whereas log SCC did not vary in the CL (5.61 vs. 5.66). This SCC reduction was very significant in the flock with the greater IMI prevalence. As a conclusion, the antibiotic formulation used as dry therapy drastically diminished IMI prevalence and SCC during the dry period in dairy ewes as a result of greater IMI cure rates and lower reinfection and new infection rates in the TL compared with the CL.
\end{abstract}

Received November 8, 2007.

Accepted May 16, 2008.

${ }^{1}$ Corresponding author: c.gonzalo@unileon.es
Key words: antibiotic treatment, dry therapy, mammary pathogen, somatic cell count

\section{INTRODUCTION}

Mastitis is the most costly disease in cattle dairy herds when adequate control procedures are not used (Natzke, 1981; Halasa et al., 2007). One of the most effective tools in mastitis control programs is antibiotic dry therapy (DT), the aim of which is to get as few infected quarters as possible at calving (Eberhart, 1986). Complete and selective DT have been assessed in dairy cows (Rindsig et al., 1978; Natzke, 1981), and their effect on IMI in that species is well known (Eberhart, 1986; Berry and Hillerton, 2002; Dingwell et al., 2002).

In dairy sheep, IMI caused by coagulase-negative staphylococci and other mammary pathogens elicit high SCC (Pengov, 2001; Ariznabarreta et al., 2002), cause damage to udder tissue (Burriel et al., 1997) and important losses of milk yield (Gonzalo et al., 1994, 2002,2004 ), and persist in a high percentage of glands from one lactation to the next (Watson and Buswell, 1984; Marco, 1994). These facts, together with the high IMI prevalence in flocks in traditional milk-producing areas (González-Rodríguez et al., 1995; Gonzalo et al., 2002; Contreras et al., 2007), make DT necessary to control IMI in this species, although DT effects on IMI dynamics during the dry period and its relationship with SCC at lambing have not been studied extensively in dairy ewes (Gonzalo et al., 2004). Indeed, the key aspects to reducing IMI prevalence during the dry period are to ensure the IMI is cured, thus avoiding persistence into the next lactation, and to prevent new infections from occurring in half-udders that are bacteriologically negative at the time of drying-off.

In addition, very few intramammary formulations are registered for use in dairy sheep in the European Union (EU), and an attempt should be made to evaluate the effectiveness of other antibiotic combinations within the mastitis control programs in this species. Parenteral treatment with penethamate hydriodide has 
been shown to be effective against streptococcal infections during lactation in dairy cattle (Rose et al., 2003), and an intramammary antibiotic dry cow preparation containing procaine penicillin, penethamate hydriodide, and framycetin sulfate decreased gram-negative clinical mastitis and was suitable for maintenance of low-milk SCC in the subsequent lactation (Bradley and Green, 2001). A first experiment designed to study the depletion of antibiotic residues in the postpartum period using this last antibiotic combination as dry ewe therapy demonstrated that antibiotic residues were not detected $\geq 54 \mathrm{~h}$ postpartum (Linage and Gonzalo, 2006), but its effectiveness against IMI during the dry period is not known in dairy sheep.

The objective of the present study was to determine the effect of an antibiotic combination containing penethamate hydriodide, benethamine penicillin, and framycetin sulfate, used as DT, on IMI dynamics and $\mathrm{SCC}$ variation during the dry period in dairy sheep.

\section{MATERIALS AND METHODS}

\section{Ewe Lots, Antibiotic Treatment, and Sampling}

A total of 435 useful half-udders of 229 Assaf ewes belonging to 2 flocks with high (56.80\%) and medium (28.37\%) IMI prevalences were randomly assigned to 2 lots: 1) control lot (CL) with 212 half-udders (111 ewes) that received no treatment and 2) treated lot (TL) with 223 half-udders (118 ewes), which received a complete DT (1 syringe per teat) consisting of 100 $\mathrm{mg}$ of penethamate hydriodide, $280 \mathrm{mg}$ of benethamine penicillin, and $100 \mathrm{mg}$ of framycetin sulfate (Mamyzin Secado, Benestermycin, Boehringer Ingelheim Spain S.A., Barcelona). This intramammary formulation is licensed in many EU countries, in Mexico, and in New Zealand for the treatment and prevention of IMI at dryoff in dairy cows; it was used off-label in sheep following the recommended instructions for use in dairy cattle. The number of ewes per lot in the high- and mediumprevalence flocks were 77 and 41 for TL and 78 and 33 for CL, respectively. The total number of ewes in the high- and medium-prevalence flocks was approximately 300 and 150, respectively, and both herds were machine-milked. Half of the ewes from each flock were randomly sampled for this study (155 and 74 ewes from the high- and medium-prevalence flocks, respectively).

For the bacteriological study, teats were aseptically sampled twice, on different days, in the $5 \mathrm{~d}$ preceding abrupt drying-off of the ewes, the second sampling coinciding with the last milking of the lactation. Teats were carefully cleaned using cotton wool soaked in $96 \%$ ethanol. After the first streams of milk were discarded, 5 to $10 \mathrm{~mL}$ from each half-udder were collected in sterile containers. Samples were kept at $4{ }^{\circ} \mathrm{C}$ until the bacteriological analysis, which was carried out immediately after arrival in the laboratory. After lambing, all half-udders were again sampled twice, on different days, in the first $5 \mathrm{~d}$ of the postpartum period, the first sampling being carrying out $<72 \mathrm{~h}$ postlambing. The sampling procedure was the same as that described for drying-off. All samplings were performed immediately before the morning milking $(0800 \mathrm{~h})$. The average duration of the dry period was $109.0 \pm 7.9 \mathrm{~d}$. Ewes with clinical mastitis or another clinical disorder presenting in the $3 \mathrm{wk}$ preceding drying-off and those that had received any antibiotic or antiinflammatory treatment in the $3 \mathrm{wk}$ preceding drying-off were excluded from this study. Three animals with clinical disorders were excluded: 2 in CL and 1 in TL.

\section{Bacteriological Procedures}

An inoculum of $0.01 \mathrm{~mL}$ of each milk sample was plated onto 5\% sheep blood agar (bioMérieux S.A., Marcy l'Etoile, France). Plates were incubated at $37^{\circ} \mathrm{C}$ and examined for bacterial growth at 24 and 48 h. Similarly to Contreras et al. (1997) and Gonzalo et al. (2002, 2004), half-udder IMI was defined as the growth of 3 or more identical colonies $(\geq 300 \mathrm{cfu} / \mathrm{mL})$. The growth of 2 different types of colonies with $\geq 300$ $\mathrm{cfu} / \mathrm{mL}$ per type was considered as a mixed culture. A sample was considered contaminated and rejected if 3 or more colony types were present on a plate. Bacteria were identified according to the recommendations of the National Mastitis Council (Harmon et al., 1990). Briefly, colonies were tentatively identified based on colony growth, morphology and appearance, pattern of hemolysis, and gram staining. Preliminary assays of catalase for the gram-positive organisms and of the oxidase (Becton, Dickinson and Company, Hunt Valley, MD) and fermentation pattern in triple sugar iron agar (Oxoid Ltd., Basingstoke, UK) for the gramnegative ones were carried out in all cases. Grampositive, catalase-negative cocci were identified as belonging to the Streptococcaceae family and subjected to the CAMP (Christie-Atkins-Munch-Petersen) test and esculin hydrolysis. The CAMP-positive, esculinnegative strains were subjected to agglutination of latex particles sensitized by Lancefield group B specific rabbit immunoglobulins (Slidex Strepto B, bioMérieux S.A.); the positive strains were identified as Streptococcus agalactiae. The gram-positive, pleomorphic, and catalase-positive coccobacilli were classified within the Corynebacterium genus, whereas the catalase-negative ones were identified as Arcanobacterium pyogenes. Definitive identification for gram-positive and gramnegative (enteric/nonfermenter) organisms was carried 
out using the BBL Crystal ID system (Becton, Dickinson and Company). Confirmation of Staphylococcus aureus was carried out with a rapid agglutination test with blue latex particles coated with porcine fibrinogen and rabbit IgG (Staphytect Plus, Oxoid Ltd.). The presence of Mycoplasma agalactiae was examined in the bulk tank milk samples and in half-udders with SCC $\geq 1,000 \times 10^{3}$ cells $/ \mathrm{mL}$, which did not present any bacterial growth following the procedure described by Gonzalo et al. (2002). A half-udder was considered infected at drying-off if the same pathogen was present in the 2 samples obtained before drying-off, and a half-udder was considered infected at parturition if the same pathogen was present in the 2 samples obtained immediately after lambing. Thirteen half-udders with inconsistent bacteriological results were excluded from this study, as well as 10 dry half-udders that could not be sampled. The final number of useful half-udders used was 435 .

The dynamics of IMI during the dry period were studied by examining cure, persistent infection, curereinfection, and new infection rates. Cure rate was the percentage of half-udders infected at drying-off and bacteriologically negative at lambing. Persistent infection rate was the percentage of half-udders infected with the same pathogen at drying-off and at lambing. Mixed infections in which one of the organisms persisted until lambing were also considered as persistent infections. Cure-reinfection rate was the percentage of half-udders that were infected with a specific pathogen at dryingoff but showed a different pathogen at lambing. New infection rate was the percentage of half-udders that were healthy at drying-off but infected at lambing.

\section{SCC}

After bacteriological analysis, SCC was determined for each milk sample using the Fossomatic method (Fossomatic 90, A/S N Foss Electric, Hillerød, Denmark). This was done 24 to $48 \mathrm{~h}$ after collection, as described by Gonzalo et al. (1993).

\section{Statistical Analyses}

Variation factors of the IMI dynamics and prevalence during the dry period were studied according to 2 categorical models, using the SAS CATMOD procedure (SAS Institute, 1998).

The categorical model used to study IMI dynamics throughout the dry period was:

$$
\mathrm{Y} \cong \mathrm{T}+\mathrm{F}+\mathrm{D}+\mathrm{P}
$$

where $\mathrm{Y}=$ the cure, persistent infection, cure-reinfection, and new infection rates; $\mathrm{T}=$ the treatment group (2 levels: CL and TL); $\mathrm{F}=$ the flock (2 levels: flock 1 and $2) ; \mathrm{D}=$ the duration of the dry period (2 levels: $\leq 120 \mathrm{~d}$ and $>120 \mathrm{~d}$ ); and $\mathrm{P}=$ the parity (2 levels: 2nd parity and $>2$ parities). The interactions treatment group $\times$ flock, treatment group $\times$ dry period duration, and flock $\times$ dry period duration were also studied, but they were not statistically significant and were excluded in the final mathematical model.

The IMI prevalence was also studied with the SAS CATMOD procedure (SAS Institute, 1998), using the following categorical model:

$$
\mathrm{Y} \cong \mathrm{T}+\mathrm{F}+\mathrm{S}+\mathrm{P}+\mathrm{TF}+\mathrm{TS}+\mathrm{FS}
$$

where $\mathrm{Y}=$ the IMI prevalence; $\mathrm{T}, \mathrm{F}$, and $\mathrm{P}=$ the same effects as in the above-mentioned model; $\mathrm{S}=$ the period of lactation (2 levels: drying-off and lambing); $\mathrm{TF}=$ the treatment group $\times$ flock interaction; $\mathrm{TS}=$ the treatment group $\times$ lactation period interaction; and FS $=$ the flock $\times$ lactation period interaction.

Differences in infection rates and prevalence were tested with a $\mathrm{X}^{2}$ analysis, using the SAS FREQ procedure (SAS Institute, 1998). The unit of study for rates and global prevalence was the half-udder, but when organism prevalence and isolates were analyzed, the unit of study was the organism because of mixed cultures.

Somatic cell count variations were studied by mixed model using the SAS MIXED procedure (SAS Institute, 1998):

$$
\begin{gathered}
\mathrm{Y}_{\mathrm{ijklm}}=\mu+\mathrm{F}_{\mathrm{i}}+\mathrm{T}_{\mathrm{j}}+\mathrm{G}_{\mathrm{k}(\mathrm{ij})}+\mathrm{S}_{\mathrm{l}}+\mathrm{P}_{\mathrm{m}}+\mathrm{FT}_{\mathrm{ij}}+\mathrm{TS}_{\mathrm{jl}} \\
+\mathrm{FS}_{\mathrm{il}}+\mathrm{FTS}_{\mathrm{ijl}}+\mathrm{e}_{\mathrm{ijklm}},
\end{gathered}
$$

where $\mathrm{Y}_{\mathrm{ijk} k \mathrm{~m}}=\log \mathrm{SCC} ; \mathrm{G}_{\mathrm{k}(\mathrm{ij})}=$ the effect half-udder within flock $\times$ treatment group interaction; $F_{i}, T_{j}, S_{1}$, and $\mathrm{P}_{\mathrm{m}}=$ the same effects as in the previous analyses; $\mathrm{FT}_{\mathrm{ij}}, \mathrm{TS}_{\mathrm{j}}, \mathrm{FS}_{\mathrm{il}}$, and $\mathrm{FTS}_{\mathrm{ijl}}=$ the flock $\times$ treatment, treatment $\times$ lactation period, flock $\times$ lactation period, and flock $\times$ treatment $\times$ lactation period interactions; and $\mathrm{e}=$ the residual effect. All effects were fixed, except $\mathrm{G}_{\mathrm{k}(\mathrm{ij})}$, which was random. In this procedure, random effect $\mathrm{G}_{\mathrm{k}(\mathrm{ij})}$ was absorbed in the analysis, and only the significance of fixed effect was shown. Least squares means and test of significance were obtained for the fixed effects of the mixed model.

\section{RESULTS AND DISCUSSION}

In the present study, $94.5 \%$ of infected half-udder observations were pure cultures, and $5.5 \%$ were mixed cultures. Mixed cultures were more frequent in the 
Table 1. Statistical analysis and $x^{2}$ statistical significance of cure, persistent infection, cure-reinfection, and new infection rates during the dry period for the factors of variation studied

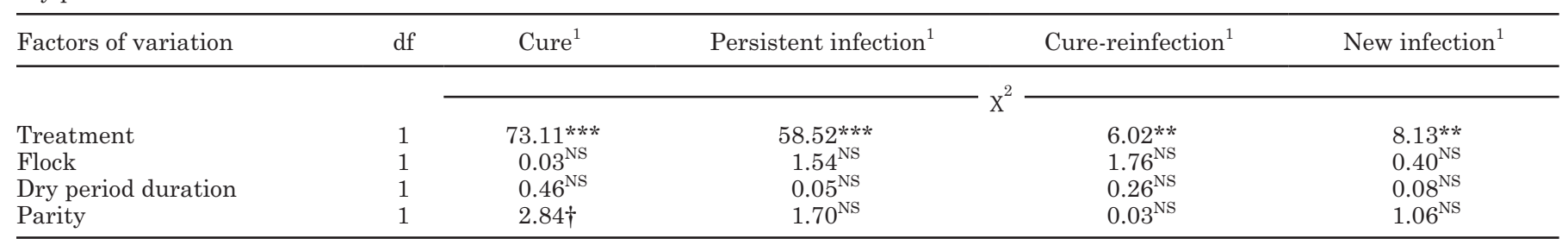

${ }^{1}$ Total number of observations for cure, persistent infection, cure-reinfection, and new infection rates $=207,207,207$, and 228 .

${ }^{\mathrm{NS}}$ Nonsignificant; $\dagger P<0.10 ;{ }^{* *} P<0.01 ;{ }^{* * *} P<0.001$.

flock with high IMI prevalence (6.6\%) compared with the flock with low prevalence (1.4\%), in accordance with results described by other authors in dairy sheep (Marco, 1994; Ariznabarreta et al., 2002).

The ANOVA for categorical model used to study the variation of IMI dynamics during the dry period (Table 1) showed that only the treatment had a significant effect $(P<0.01$ to $P<0.001)$ on all cure, persistent infection, cure-reinfection, and new infection rates. Other factors, such as dry period duration or flock effects, did not contribute significantly to variations in the studied rates.

Table 2 shows the values of the variables studied in the 2 treatment groups. Differences between lots were very important $(P<0.001)$ for cure rates: $81.7 \%$ in the TL vs. $13.3 \%$ in the CL. Conversely, persistent infections were greater in the CL compared with the TL (70.4 vs. $12.8 \%)$. Cure rates were similar to those obtained by other authors in dairy sheep using intramammary infusions containing cloxacillin and ampicillin (86.0\%) (Marco, 1994), or penicillin and novobiocin (82.6 to $84.4 \%$; Tardáguila, 1999 ), and greater than cure rates obtained by Chaffer et al. (2003) in Assaf ewes dry-treated with a combination of penicillin, nafcillin, and dihydrostreptomycin (64.9\%). In the TL, bacteriological cure involved 89 half-udders infected at drying-off with Staphylococcus epidermidis (69.7\% of total cured half-udders), Strep. agalactiae (10.1\%),
Corynebacterium spp. (5.6\%), Staphylococcus simulans (4.5\%), other CNS (5.5\%), Staph. aureus (3.4\%), Arc. pyogenes (2.2\%), Micrococcus kristinae (1.1\%), Enterococcus faecalis (1.1\%), and Pseudomonas spp. (1.1\%). These percentages total up to $104.3 \%$ due to the fact that some samples had 2 isolates (mixed infections). Auto-cure in the CL was only evidenced in 13 half-udders, 9 of which were infected at drying-off with Staph. epidermidis.

Reinfection and new infection rates were also lower $(P<0.01)$ in the TL $(5.5$ and $7.9 \%$, respectively) vs. the CL (16.3 and $22.8 \%$, respectively), which may indicate a preventive effect of DT against IMI during the dry period, particularly in dairy sheep flocks with mediumhigh IMI prevalences. This prophylactic use of DT to prevent new infections during dry period has also been described in dairy cattle (Dingwell et al., 2002). In a very extensive study in 24 dairy herds, these authors demonstrated that the probability of quarters developing new IMI during the dry period was greater in the cows that had longer dry periods. However, the dry period duration effect was not significant in our study, in which the 35 new IMI recorded (Staph. epidermidis: 22; Staph. simulans: 4; Staph. aureus: 3, of which 1 was clinical mastitis; Streptococcus uberis: 3; Corynebacterium spp.: 2; and Aspergillus fumigatus: 1 ) were mainly caused by contagious pathogens. New infection caused by Asp. fumigatus could be the result of iatrogenic

Table 2. Cure, persistent infection, cure-reinfection, and new infection rates in control and treated ewe lots, showing the statistical significance for the differences between lots

\begin{tabular}{lccc}
\hline Rate (half-udder level) & Control lot & Treated lot & $P$-value \\
\hline Cure (\%) & 13.27 & 81.65 & $<0.001$ \\
$\left(\mathrm{n}^{1} / \mathrm{N}^{2}\right)$ & $(13 / 98)$ & $(89 / 109)$ & $<0.001$ \\
Persistent infection (\%) & 70.41 & 12.84 & \\
$(\mathrm{n} / \mathrm{N})$ & $(69 / 98)$ & $(14 / 109)$ & $<0.01$ \\
Cure-reinfection (\%) & 16.33 & 5.50 & $<0.01$ \\
$(\mathrm{n} / \mathrm{N})$ & $(16 / 98)$ & 7.89 & \\
New infection (\%) & 22.81 & $(9 / 114)$ & \\
$(\mathrm{n} / \mathrm{N})$ & $(26 / 114)$ & & \\
\hline
\end{tabular}

${ }^{1}$ Number of half-udders concerned in each rate.

${ }^{2}$ Total number of half-udders. 
Table 3. Statistical analysis and $x^{2}$ statistical significance of intramammary infection prevalence for the factors of variation studied $^{1}$

\begin{tabular}{lcc}
\hline Source of variation & df & $\mathrm{X}^{2}$ \\
\hline Treatment & 1 & $30.14^{* * *}$ \\
Flock & 1 & $29.40^{* * *}$ \\
Lactation period & 1 & $16.34^{* * *}$ \\
Parity & 1 & $1.80^{\mathrm{NS}}$ \\
Treatment $\times$ flock & 1 & $0.60^{\mathrm{NS}}$ \\
Treatment $\times$ lactation period & 1 & $47.71^{* * *}$ \\
Flock $\times$ lactation period & 1 & $2.23^{\mathrm{NS}}$ \\
\hline
\end{tabular}

${ }^{1}$ Total number of observations of categorical model $=870$.

${ }^{\mathrm{NS}}$ Nonsignificant; ${ }^{* * *} P<0.001$.

contamination at the time of DT application (Pérez et al., 1998; Gonzalo et al., 2004), although the teats were disinfected with fast-acting iodine before syringe insertion, and syringes were under strict hygiene conditions during application. Syringes were not reinserted.

The causes of variation in IMI prevalence during the dry period are shown in Table 3. Antibiotic treatment, flock, lactation period, and treatment $\times$ lactation period were statistically significant effects. Similar IMI prevalences $(P>0.05)$ were found at drying-off both in the CL (46.2\%) and the TL (48.9\%). However, the IMI prevalences at lambing were very different $(P<$ 0.001 ) between both lots: $52.4 \%$ for the CL and $13.0 \%$ for the TL after DT using the antibiotic combination studied. This reduction in IMI prevalence $(75.2 \%)$ evidenced in the TL compared with the CL was slightly greater than that found with other antibiotic preparations such as penicillin-novobiocin (61.5 to $64.9 \%)$ or cloxacillin-ampicillin (69.5\%) in dairy sheep (Marco,
1994; Tardáguila, 1999) and summarized the global effectiveness of the antibiotic DT used in this study. Although the IMI prevalences at drying-off were very different between the 2 flocks involved in the experiment (56.8 and 28.4\%), the antibiotic treatment effect was similar in both flocks, because IMI prevalence was reduced significantly in both flocks over the studied time period (Table 4). Furthermore, there was a trend toward increased IMI prevalence in the CL of both flocks during the dry period (Table 4), probably due to an increase in new infections (i.e., Staphylococcus spp. other than Staph. epidermidis) as shown in Table 5, although these differences in prevalence were not statistically significant for the CL.

The greatest prevalences were observed for the Staphylococcus and Streptococcus genera (Table 5), according with the results of Gonzalo et al. (2002) and Contreras et al. (2007) in dairy sheep. For the TL, the prevalence of staphylococci drastically diminished $(P<$ $0.001)$ between drying-off (41.3\%) and lambing (9.9\%), as did the prevalence of streptococci (5.8 to $1.8 \%$, respectively, $P<0.05)$. More specifically, the decrease in prevalence during the dry period was very significant for Staph. epidermidis (34.1 to 7.6\%) and Strep. agalactiae (5.8 to $0.9 \%$ ). These results were consistent with those of a study reporting bacteriological cure in 59\% of penethamate-treated quarters with Strep. uberis or Streptococcus dysgalactiae infection in dairy cattle during lactation (Rose et al., 2003). In the present study, the bacteriological cure for Strep. agalactiae during the dry period was $84.6 \%$ after antibiotic treatment. For the CL, however, variations in prevalence were not significant except for Staphylococcus spp. (other than

Table 4. Intramammary infection prevalence during the dry period for each flock, treatment lot, and for the total, indicating the $\mathrm{X}^{2}$ test and the statistical significance for the differences between drying-off and lambing

\begin{tabular}{|c|c|c|c|}
\hline Treatment & Drying-off & Lambing & $x^{2}$ \\
\hline \multicolumn{4}{|l|}{ Flock1 } \\
\hline $\begin{array}{l}\text { Control lot } \\
\left(\mathrm{n}^{1} / \mathrm{N}^{2}\right)\end{array}$ & $\begin{array}{c}53.02 \\
(49 / 149)\end{array}$ & $\begin{array}{c}57.05 \\
(85 / 149)\end{array}$ & $0.49^{\mathrm{NS}}$ \\
\hline $\begin{array}{l}\text { Treated lot } \\
(\mathrm{n} / \mathrm{N})\end{array}$ & $\begin{array}{c}60.69 \\
(88 / 145)\end{array}$ & $\begin{array}{l}15.17 \\
(22 / 145)\end{array}$ & $63.80 * * *$ \\
\hline \multicolumn{4}{|l|}{ Flock 2} \\
\hline $\begin{array}{l}\text { Control lot } \\
(\mathrm{n} / \mathrm{N})\end{array}$ & $\begin{array}{c}30.16 \\
(19 / 63)\end{array}$ & $\begin{array}{c}41.27 \\
(26 / 63)\end{array}$ & $1.69^{\mathrm{NS}}$ \\
\hline $\begin{array}{l}\text { Treated lot } \\
(\mathrm{n} / \mathrm{N})\end{array}$ & $\begin{array}{c}26.92 \\
(21 / 78)\end{array}$ & $\begin{array}{c}8.97 \\
(7 / 78)\end{array}$ & $8.53^{* *}$ \\
\hline \multicolumn{4}{|l|}{ Total } \\
\hline $\begin{array}{l}\text { Control lot } \\
(\mathrm{n} / \mathrm{N})\end{array}$ & $\begin{array}{c}46.23 \\
(98 / 212)\end{array}$ & $\begin{array}{c}52.36 \\
(111 / 212)\end{array}$ & $1.59^{\mathrm{NS}}$ \\
\hline $\begin{array}{l}\text { Treated lot } \\
(\mathrm{n} / \mathrm{N})\end{array}$ & $\begin{array}{c}48.88 \\
(109 / 223)\end{array}$ & $\begin{array}{c}13.00 \\
(29 / 223)\end{array}$ & $67.16^{* * *}$ \\
\hline
\end{tabular}

${ }^{1}$ Number of half-udders infected.

${ }^{2}$ Total number of half-udders.

${ }^{\mathrm{NS}}$ Nonsignificant; ${ }^{* *} P<0.001 ;{ }^{* * *} P<0.001$. 
Table 5. Number of isolates and prevalences of bacterial species and groups found in each treatment lot and lactation period

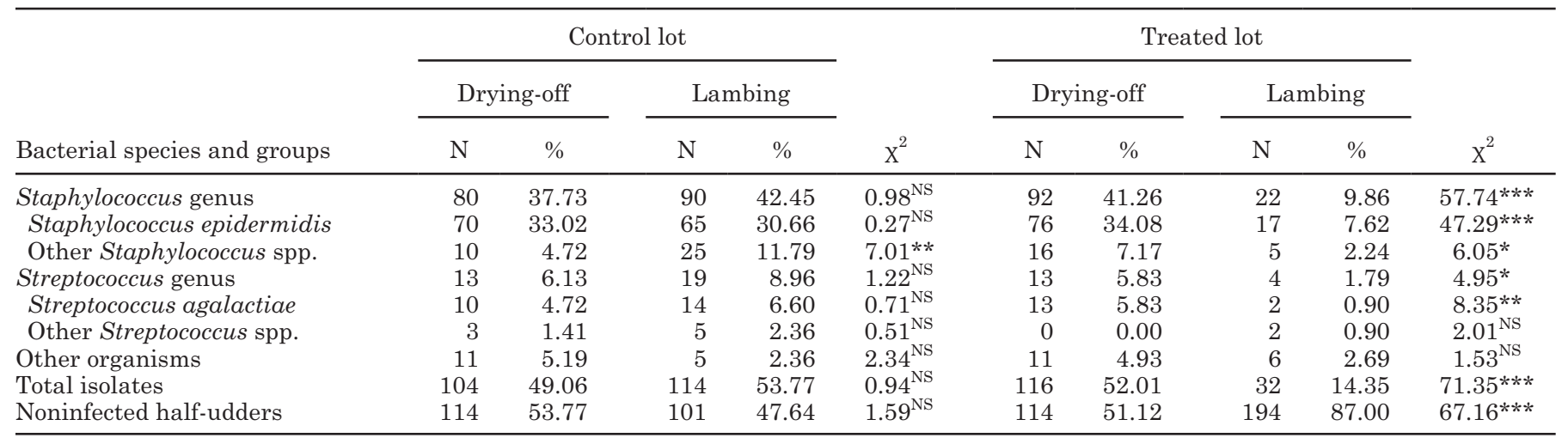

${ }^{\text {NS Nonsignificant; }{ }^{*} P<0.05 ;{ }^{* *} P<0.01 ;{ }^{* * *} P<0.001}$

Staph. epidermidis), which increased $(P<0.01)$ during the dry period (Table 5). Other organisms had very low prevalences. The prevalence of half-udders with clinical mastitis at lambing was also low (2 isolates in the CL and 0 in the TL) and corresponded to Staph. aureus isolates from the flock with the greater IMI prevalence. Mycoplasma agalactiae was not isolated from bulk tank milk or from half-udders.

Several studies have revealed the predictive value of the SCC and its efficacy in diagnosing infection in dairy ewes (González-Rodríguez et al., 1995; Gonzalo et al., 2002). Consequently, the SCC can be used as a suitable tool for monitoring mammary health and as part of mastitis control strategies in dairy sheep. A test of significance for all SCC variation factors studied is shown in Table 6. The half-udder was the most important factor influencing log SCC variation, because it accounted for $40.7 \%$ of total variance. Flock, treatment, lactation period, flock $\times$ treatment, lactation period $\times$ treatment, flock $\times$ lactation period, and flock $\times$ lactation period $\times$ treatment contributed significantly to the variation of log SCC. Thus, as shown in Table 7, log SCC decreased $(P<0.001)$ between drying-off (5.68) and lambing (5.33) for the TL but did not vary $(P>0.05)$ for the CL $(5.61 \mathrm{vs.}$ 5.66). Overall, these results showed an improvement in SCC during the beginning of the subsequent lactation in treated ewes, which concurs with IMI dynamics and the reduction in IMI prevalence found for the TL in this study. These results were consistent with lower bulk tank milk SCC found in dairy ewe flocks implementing dry-ewe therapy (Gonzalo et al., 2005). Nevertheless, SCC variation was not significant in the flock with the lowest IMI prevalence, where log SCC was similar at drying-off (5.26) and at lambing (5.23) in treated ewes (Table 7). This was probably due to a low IMI prevalence of major pathogens (3 isolates of Staph. aureus and 1 isolate of $E$. faecalis at drying-off and 1 isolate of Staph. aureus at lambing) eliciting high SCC in this flock. Thus, the prevalence decrease in treated ewes corresponded mainly to minor pathogens $(23.1 \%$ at drying-off to $8.9 \%$ at lambing). The improvement in the hygienic quality of milk, particularly in the flock with a greater IMI prevalence, demonstrated improved mammary health in the TL and showed the particular importance of antibiotic DT in attaining the ewe milk quality standards for SCC demanded of producers by the milk industry.

Regarding antibiotic depletion in the postpartum period, the presence of residual antibiotics in 50 Assaf ewes (100 glands) dry-treated with the same antibiotic formulation (1 syringe/teat) was measured in colostrum and milk in the first 7 milkings postpartum previously to the present study (Linage and Gonzalo, 2006). The detection method was the Blue-Yellow screening test (Charm Sciences Inc., Lawrence, MA) recently adapted for ovine milk (Linage et al., 2007), the detection limits (3 to $4 \mu \mathrm{g} / \mathrm{kg}$ for penicillin and 704 to $781 \mu \mathrm{g} / \mathrm{kg}$ for framycetin) being lower than maximum residue limits established by EU in ovine milk $(4 \mu \mathrm{g} / \mathrm{kg}$ and $1,500 \mu \mathrm{g} /$ $\mathrm{kg}$, respectively). Antibiotic residues were not detected

Table 6. Statistical analysis of $\log$ SCC for the factors of variation studied, indicating their test of significance ${ }^{1}$

\begin{tabular}{lcc}
\hline Source of variation & df & $F$ \\
\hline Treatment & 1 & $5.86^{* *}$ \\
Flock & 1 & $134.96^{* * *}$ \\
Lactation period & 1 & $48.63^{* * *}$ \\
Parity & 1 & $1.91^{\mathrm{NS}}$ \\
Flock $\times$ treatment & 1 & $4.63^{*}$ \\
Lactation period $\times$ treatment & 1 & $48.22^{* * *}$ \\
Flock $\times$ lactation period & 1 & $58.35^{* * *}$ \\
Flock $\times$ lactation period $\times$ treatment & 1 & $22.58^{* * *}$ \\
\hline
\end{tabular}

${ }^{1}$ Half-udder within flock $\times$ treatment: random factor absorbed in the model. Number of half-udders $=435$. Number of observations $=1,740$.

${ }^{\mathrm{NS}}$ Nonsignificant; ${ }^{*} P<0.05 ;{ }^{* *} P<0.01 ; * * * P<0.001$. 
Table 7. Least squares means of log SCC (LSM), standard errors (SE), and SCC geometric means $\left(\times 10^{3} / \mathrm{mL}\right.$; GM) in control and treated lots by lactation period, for each flock and for the total

\begin{tabular}{|c|c|c|c|c|}
\hline \multirow[b]{2}{*}{ Flock } & \multicolumn{2}{|c|}{ Control lot } & \multicolumn{2}{|c|}{ Treated lot } \\
\hline & Drying-off & Lambing & Drying-off & Lambing \\
\hline \multicolumn{5}{|l|}{ Flock 1} \\
\hline LSM & $6.05^{\mathrm{a}}$ & $5.98^{\mathrm{a}}$ & $6.07^{\mathrm{a}}$ & $5.46^{\mathrm{b}}$ \\
\hline $\mathrm{SE}$ & 0.06 & 0.06 & 0.06 & 0.06 \\
\hline GM & 1,122 & 955 & 1,174 & 288 \\
\hline \multicolumn{5}{|c|}{ Flock 2} \\
\hline LSM & $5.23^{\mathrm{a}}$ & $5.29^{\mathrm{a}}$ & $5.26^{\mathrm{a}}$ & $5.23^{\mathrm{a}}$ \\
\hline $\mathrm{SE}$ & 0.08 & 0.08 & 0.08 & 0.08 \\
\hline GM & 170 & 195 & 182 & 169 \\
\hline \multicolumn{5}{|l|}{ Total } \\
\hline LSM & $5.61^{\mathrm{a}}$ & $5.66^{\mathrm{a}}$ & $5.68^{\mathrm{a}}$ & $5.33^{\mathrm{b}}$ \\
\hline $\mathrm{SE}$ & 0.06 & 0.06 & 0.06 & 0.06 \\
\hline GM & 407 & 457 & 478 & 213 \\
\hline
\end{tabular}

${ }^{a, b}$ Means in the same row with different superscripts differ $(P<0.05)$.

$\geq 54 \mathrm{~h}$ postpartum; consequently, this delay may be considered as relevant to respect maximum residue limits as established by the EU in dairy ewes. Nevertheless, in the present experiment, the withdrawal time was 7 $\mathrm{d}$ as stated in the case of exceptional prescription according to Spanish rules (R.D. 109/1995, B.O.E. No. 53, 03/March/1995).

\section{CONCLUSIONS}

The original combination of penethamate hydriodide, benethamine penicillin and framycetin sulfate evaluated in this study as dry ewe therapy was very efficient in reducing IMI prevalence and improving milk SCC at lambing. These effects were related to greater IMI cure rate and lower reinfection and new infection rates during the dry period in treated ewes compared with nontreated ones.

\section{ACKNOWLEDGMENTS}

This paper was developed within the Plan Nacional I+D+i: project PETRI 95-0839.OP between the University of León (Spain) and the Consortium for Ovine Promotion in Castilla-León, Villalpando, Zamora (Spain). We thank Boehringer Ingelheim Spain S.A. for their cooperation.

\section{REFERENCES}

Ariznabarreta, A., C. Gonzalo, and F. San Primitivo. 2002. Microbiological quality and somatic cell count of ewe milk with special reference to staphylococci. J. Dairy Sci. 85:1370-1375.

Berry, E. A., and J. E. Hillerton. 2002. The effect of selective dry cow treatment on new intramammary infection. J. Dairy Sci. 85:112-121.
Bradley, A. J., and M. J. Green. 2001. An investigation of the impact of intramammary antibiotic dry cow therapy on clinical coliform mastitis. J. Dairy Sci. 84:1632-1639.

Burriel, A. R. 1997. Dynamics of intramammary infection in the sheep caused by coagulase-negative staphylococci and its influence on udder tissue and milk composition. Vet. Rec. 140:419-423.

Chaffer, M., G. Leitner, S. Zamir, M. Winkler, N. Ziv, and A. Saran. 2003. Efficacy of dry-off treatment in sheep. Small Rumin. Res. $47: 11-16$

Contreras, A., J. C. Corrales, A. Sánchez, and D. Sierra. 1997. Persistence of caprine intramammary pathogens throughout lactation. J. Dairy Sci. 80:2815-2819.

Contreras, A., D. Sierra, A. Sánchez, J. C. Corrales, J. C. Marco, M. J. Paape, and C. Gonzalo. 2007. Mastitis in small ruminants. Small Rumin. Res. 68:145-153.

Dingwell, R. T., T. F. Duffield, K. E. Leslie, G. P. Keefe, L. DesCoteaux, D. F. Kelton, K. D. Lissemore, Y. H. Schukken, P. Dick, and R. Bagg. 2002. The efficacy of intramammary tilmicosin at dryingoff, and other risk factors for the prevention of new intramammary infections during the dry period. J. Dairy Sci. 85:3250-3259.

Eberhart, R. J. 1986. Management of dry cows to reduce mastitis. J. Dairy Sci. 69:1721-1732.

González-Rodríguez, M. C., C. Gonzalo, F. San Primitivo, and P. Cármenes. 1995. Relationship between somatic cell count and intramammary infection on the half-udder in dairy ewes. J. Dairy Sci. 78:2753-2759.

Gonzalo, C., A. Ariznabarreta, J. A. Carriedo, and F. San Primitivo. 2002. Mammary pathogens and their relationship with somatic cell count and milk yield losses in dairy ewes. J. Dairy Sci. 85:1460-1467.

Gonzalo, C., J. A. Baro, J. A. Carriedo, and F. San Primitivo. 1993. Use of Fossomatic method to determine somatic cell counts in sheep milk. J. Dairy Sci. 76:115-119.

Gonzalo, C., J. A. Carriedo, J. A. Baro, and F. San Primitivo. 1994. Factors influencing variation of test day milk yield, somatic cell count, fat and protein in dairy sheep. J. Dairy Sci. 77:15371542 .

Gonzalo, C., J. A. Carriedo, M. A. Blanco, E. Beneitez, M. T. Juárez, L. F. De La Fuente, and F. San Primitivo. 2005. Factors of variation influencing bulk tank milk somatic cell count in dairy sheep. J. Dairy Sci. 88:969-974.

Gonzalo, C., J. A. Tardáguila, L. F. De La Fuente, and F. San Primitivo. 2004. Effects of selective and complete dry therapy on prevalence of intramammary infection and on milk yield in the subsequent lactation in dairy ewes. J. Dairy Res. 71:33-38.

Halasa, T., K. Huijps, O. Østeras, and H. Hogeveen. 2007. Economic effects of bovine mastitis and mastitis management: A review. Vet. Q. 29:18-31. 
Harmon, R. J., R. J. Eberhart, D. E. Jasper, B. E. Langlois, and R. A. Wilson. 1990. Microbiological Procedures for the Diagnosis of Bovine Udder Infection. National Mastitis Council Inc., Arlington VA.

Linage, B., and C. Gonzalo. 2006. Residuos antibióticos en el periodo postparto tras terapias de secado en el ovino lechero. Pages 291293 in Actas XXI Jornadas SEOC, 2006, Zamora.

Linage, B., C. Gonzalo, J. A. Asensio, M. A. Blanco, L. F. De La Fuente, and F. San Primitivo. 2007. Performance of Blue-Yelow screening test for antimicrobial detection in ovine milk. J. Dairy Sci. 90:5374-5379.

Marco, J. C. 1994. Mastitis en la oveja Latxa: Epidemiología, diagnóstico y control. $\mathrm{PhD}$ Thesis. Univ. Zaragoza, Spain.

Natzke, R. P. 1981. Elements of mastitis control. J. Dairy Sci. 64:1431-1442.

Pengov, A. 2001. The role of coagulase-negative Staphylococcus spp. and associated somatic cell counts in the ovine mammary gland. J. Dairy Sci. 84:572-574.

Pérez, V., J. M. Corpa, J. F. García-Marín, J. J. Adúriz, and H. E. Jensen. 1998. Mammary and systemic aspergillosis in dairy sheep. Vet. Pathol. 35:235-240.
Rindsig, R. B., R. G. Rodewald, A. R. Smith, and S. L. Spahr. 1978 Complete versus selective dry cow therapy for mastitis control. J. Dairy Sci. 61:1483-1497.

SAS Institute. 1998. SAS User's Guide. SAS Institute Inc., Cary, NC.

St. Rose, S. G., J. M. Swinkels, W. D. Kremer, C. L. Kruitwagen, and R. N. Zadoks. 2003. Effect of penethamate hydriodide treatment on bacteriological cure, somatic cell count and milk production of cows and quarters with chronic subclinical Streptococcus uberis or Streptococcus dysgalactiae infection. J. Dairy Res. 70:387394.

Tardáguila, J. A. 1999. Estrategias de control de mastitis basadas en la terapia antibiótica de secado en el ganado ovino de raza Churra. PhD Thesis. Universidad de León, Spain.

Watson, D. J., and J. F. Buswell. 1984. Modern aspects of sheep mastitis. Br. Vet. J. 140:529-534. 